\title{
From Collective Memory to Transcultural Remembrance
}

\author{
Matthew Graves, University of Provence, and \\ Elizabeth Rechniewski, University of Sydney
}

In memory of François Poirier (1947-2010), Director of the Centre for Intercultural Research in the English-and French-speaking Worlds (University of Paris XIII) who showed the way.

'Whispering lunar incantations

Dissolve the floors of memory' (TS Eliot)

\section{The crisis of history and the turn to memory}

We can identify a 'turn to memory' in both the policies and practices of state and community organisations and the attention of the academic community over the last thirty years or so, a period that roughly corresponds to what, in the 1980s, Pierre Nora described as the 'era of commemoration.' There are many explanations offered for this turn; its existential origins include the 'crisis of history,' a particular example of the broader crises in representation that flow from the collapse of linear conceptualisations of time and progress and of the grand narratives of the past two centuries. David Harvey refers to this transformation of concepts of temporality as 'time-space compression': the acceleration of time and shrinking of space through globalisation that affects our sense of our place in the world, and our very idea of self (2001: 123-24). Resort to memory is one form of resistance to the 'utopia' of globalisation, a way of re-anchoring ourselves in space and time; the redemptive power of memory is compensation for the social and psychological disruption of 'super modernity' and the 'loss of place,' of rootedness, that accompanies it (Augé 1995). Memory seems to offer the authenticity that history has 
lost, one that claims to be based on direct transmission, lived experience or family or community tradition. And yet the turn to memory is in itself a symptom of its own decline: students of collective memory have long recognised that it is precisely when memory begins to lose its power and its salience in determining individual and communal daily life that it becomes necessary to consciously promote it, to concretise it in ritual and record, to revive or reinvent it through the construction of 'traditions.'

On the political level, this 'era of commemoration,' this 'memory boom' in Jay Winter's words (2006), has been characterised by the recovery and confident assertion of memory by groups and communities who oppose their counter-memories to the official narratives. The brassage of populations, as the inhabitants of former colonies migrate to the metropole to work, creates a focus for organisation in the heartland of the former oppressor; and the rise of the ideology of multiculturalism allows alternative voices to be heard. Memories of once oppressed groups are marshalled in demand for financial compensation (damages, pensions), redistribution of political resources (representation in parliament; treaties), and symbolic recognition (apologies), and for their presence to be made visible and public (monuments; museums). The imminent end of communicative memory, as personal recollection of events such as the two World Wars passes into 'cultural memory'-representations that lack the immediacy of firsthand experience - has resulted in an unprecedented crescendo of contestation over the interpretation of the past and the content of the future cultural memory. For example, Rechniewski's article in this issue on the successful campaign to inaugurate a 'Battle for Australia Day' illustrates the crucial inter-generational role of veterans' organisations in seeking to ensure recognition of their role and perspective on World War II.

While far from espousing technological determinism, we can cite the role of technological advances, beginning with the invention of the compact audio-cassette recorder in the 1960s, which have made the collection and dissemination of data such as oral history much easier, and which today make it possible for groups to set up web sites as virtual lieux de mémoire for marginalised memories and that give a world-wide platform to interest groups and communities campaigning to have their memories heard: veterans, for example, who feel that a war or battle has been forgotten (the Korean War) or misrepresented (the Vietnam War). 


\section{'Take-off' of the academic study of memory}

This 'turn to memory' has been paralleled in the academic field as memory studies has emerged over the past two decades as an interdisciplinary field in its own right, with specialist journals, conferences, research centres (The Centre for the Study of Cultural Memory at the University of London offers degree programs) and publications such as Memory Studies (from 2008) and the longer-established History and Memory (from 1990). Early work in this period on the topic of memory and commemoration often focused on the national scale. We could cite the example of Benedict Anderson, whose influential Imagined Communities (1983) focuses on the role of the state and nationwide institutions (vernacular print media, education, royalty, museums) in fostering remembrance and therefore national identity, albeit in a transcolonial or postcolonial context. Another example is Pierre Nora (1984-1992), who is responsible for the notion of the nation-mémoire: this nation-memory is materialised in the lieux de mémoire, each site - place, object, event, or category_representing metonymically the whole of France. These and other studies — stretching back to Émile Durkheim and his notion of the conscience collective (1893), which applied to society as a whole and was the glue that bound it together - tend to assume a coherent 'spread' of collective memory across society that hegemonically fills up the national space and ends at its borders.

More recently, however, there has been increasing awareness of the dangers involved in reifying the concept of collective memory, and of the need to recognise the fractured and conflictual nature of memory within and across state borders. Critics of Nora's project, such as Alon Confino (1997), Hue-Tam Ho Tai (2001), and Perry Anderson (2004), condemned its focus on the nation-state and its suppression of countervailing voices - its 'bureaucratic centralization' in Ho Tai's words (2001). In the context of globalisation and access to an ever-broadening range of media, as the 'same' events are constantly being represented and commented from different points of view, exposing the relativity of national perspectives and encouraging the comparative framework that should always have been present, 'transnational' and 'transcultural' have come to challenge the dominance of national viewpoints. There is an important and useful distinction to be made between transnational and transcultural. The term transnational can leave national boundaries intact; a transcultural approach refuses to acknowledge national boundaries and allows us to consider not only cultures that may transcend 
national borders, but those multiple and diverse subcultures that exist within them; it reminds us of the need to examine not only the supra- but the infra-national level. ${ }^{1}$ The European context of much recent academic research challenges the 'ideal of national cultural integrity': 'transcultural diversity ha[s] by now become an integral aspect of the social landscape of Europe' (Robins 2006: 276). Moreover, developing study of cities and cosmopolitanism 'provide better cognitive tools than nations for reimagining the new interdependencies and flows of contemporary societies' (Meinhof \& Triandafyllidou 2006: 13). Such studies draw attention to the significance of influence between and across cultures, recently evoked in Michael Rothberg's Multidirectional Memory (2009); they recognise the role of intermediaries, passeurs, who introduce and interpret acts and narratives of memory within the communities/cultures in which they hold power, authority or symbolic capital. The role of influence and imitation across cultures is recognised by Andreas Huyssen (2003) who has diagnosed a 'globalization of traumatic memory discourses' in which the tropes and rhetoric of the Holocaust played an increasingly prominent role in different national and political contexts. Researchers themselves are transcultural operators who interpret remembering cultures to themselves and others, and contribute to disseminating practices of remembrance across cultures.

It is only very recently, however, that the term transcultural as been used in memory studies, as some researchers - notably Astrid Erll—-have begun exploring an approach, a 'specific research perspective,' that recognises the 'inherent transculturality of memory.' In February 2010 Erll gave an address to the Conference on Transcultural Memory at Goldsmiths College, in which she develops the idea of 'travelling memory' to represent 'the incessant wanderings of content, forms and media of memory across linguistic and national boundaries' (Erll 2010). It is important, nonetheless, to avoid personifying memory: memory doesn't travel, but people do, carrying and spreading memory. And if in the title to this article we use the expression 'transcultural remembrance,' it is because, as Jay Winter argues, the term 'remembrance' lays the emphasis on the act of remembering; it focuses on 'specifying agency, on answering the

\footnotetext{
${ }^{1}$ The extensive theoretical discussions since 1940 in other disciplines, notably Latin American, Latino and Postcolonial Studies, around the notion of 'transculturation' have as yet had little impact in the field of memory studies. We use the term in the limited sense defined here. For a detailed discussion of the term's origins in Latin American critical discourse and its subsequent applications, see Allatson (2007: 229-32).
} 
question who remembers, when, where and how' (2006: 3), and it draws attention to the actors involved in the production but also the dissemination and the reception of memory across and within national boundaries.

If the production and consecration of memory by the state and civil institutions has been well studied in many countries, the problem of the dissemination and reception by different sections of the population has been much less so (and is less easy to study). It is increasingly clear that the responses to official commemoration and memorialism vary widely according to cultural difference, ethnic identification, generation, class and gender. We could cite as an example the differential response of women and men to the slaughter of World War I. Unlike other studies in this area, Joy Damousi (1999) considers how mourning affected men and women in different ways, and analyses the gendered dimensions of grief and memory. These are not necessarily essential gender differences but cultural differences based on social position, socialisation and the historical tendency for women to be associated with, if not confined to, the private, domestic sphere, and men with the public. The collection of essays edited by Sylvia Paletschek and Sylvia Schraut (2008) provides other examples of how the social position of women in a range of cultures affects their memory practice. Moreover, the 'national orientation of public memory in connection wth the norms of the bourgeois gender-model' (23) tends to militate against the participation of women in official forms of public remembering. Can the difference between male and female remembering be represented as the distinction between the official and vernacular made by John Bodnar (1992), the official 'male' remembering propagated by state and voluntary institutions, such as the Returned and Services League of Australia (RSL), through public, organised, narrativised events; while female remembering is the vernacular, unofficial memory kept alive within the family and community sphere, often not finding expression in the larger arenas? Cultural differences in remembering are also evident in Eugen Weber's study of the peasants in late $19^{\text {th }}$ century France (1976). Weber revealed that the peasants simply did not recognise (or misinterpreted) the events and figures that memorialised the national unity so assiduously constructed by the middle classes and the elites

These examples indicate the potential role of subcultures as the source of countermemories, opposing official narratives. However, it is important not to credit counter- 
memories as being necessarily more 'authentic' than official narratives. Calling for a new history in 1971, Foucault 'celebrated the transgressive aspects of counter memory as 'liberating, divergent and marginal elements,' but in later years 'developed an analysis of power that explicitly argued against romanticising the margins as inherently liberatory' (Bal et al. 1999: 216). There are no spaces 'outside power,' and counter memories always exist in relation to the dominant paradigms they contest. They can, moreover, be taken over, absorbed into the mainstream in a dynamic process of reinterpretation, appropriation and recuperation. Such is the power and spread of the national and international media today that few '(sub)cultural memories' are untouched by national, transnational, and transcultural perspectives.

The term transcultural draws attention finally to the intersection and confrontation of cultures. It opens new lines of inquiry into the ways in which memory sites and figures of memory may become the subject of a struggle for 'ownership' on the part of different groups, a struggle for 'symbolic capital' in Bourdieu's terms (1993), but a struggle that may also, as we have suggested, have financial and other implications. The articles in this issue illustrate the kinds of conflict that take place around the ownership of memories: who has the right and the means to impose their memories in wider arenas? What stories are they allowed to tell? What political ideologies and vested interests promote or oppose the re-examination of the past? As Le Goff writes: 'memory is a stake in the power game' (1992: 114). Rechniewski's article in this issue on the 'Battle for Australia Day' illustrates how much can be at stake in conflicts over the right to remember the past, and the right way to remember the past; and the ways in which memory can be used as political strategy, to condemn political opponents as cowardly and incompetent, or to justify current policies, such as the war in Iraq. Judith Keene's article illustrates how Cold War attitudes - crystallised in the film The Manchurian Candidate-have for so long dominated the remembrance of the Korean War in the USA and elsewhere, despite the protests and campaigns for recognition by the war's veterans.

\section{Memory as praxis}

Jeffrey Ollick poses the question: 'are individual memory, social and cultural frameworks and collective representations really separate things?' And he answers in the negative, arguing for the need to reframe collective memory as a wide variety of 
mnemonic products and practices that define, stabilise through repetition and ritual, and instantiate individual and collective identities (2008: 158). To emphasise that collective memory is something we do rather than something we have, as Ollick does, allows us to recalibrate the study of memory as a series of questions about agents and actions: who oversees the practices, who are the participants, what rites and rituals are observed, what stories are told? But whereas Ollick describes memory as a 'fluid negotiation between the desires of the present and the legacies of the past' (2008: 159) — a pacific description-we would see it rather as a site of interaction, tension, even of conflict.

Timothy Ashplant et al. (2004) distinguish three aspects of the struggle to articulate the memory of war, which we can extend to the study of memory more generally: narratives, arenas and agencies of articulation. Narratives of articulation 'refer to the shared formulations within which social actors couch their memories'-from hegemonic official narratives, through oppositional counter memories, to locally shared or individual accounts (16). Such narratives often call on templates offered by existing national but also religious and political discourses, and increasingly by the discourse of human rights (69). Arenas of articulation refer to 'the socio-political spaces within which social actors advance claims for the recognition of specific [war] memories' and for associated benefits. They range from networks of families or kinship groups, through communities of geography or interest (returned soldiers of a particular unit or battle), to the public sphere of nation states and transnational power blocs (17). Agencies of articulation 'refer to those institutions through which social actors seek to promote and secure recognition of their war memories' (17) - they encompass the official bodies of the nation state, the organisations and movements of civil society and more informal localised face-to-face groupings.

To these categories should be added 'modes of articulation,' the channels through which memories are revived, constructed and reconstructed: monuments and museums (including the virtual); cinema and television series and documentaries; fiction, song and poetry; mapping and graphic design; biographies and autobiographies; the writings of professional and amateur historians; and, increasingly nowadays, the internet and websites. ${ }^{2}$ Judith Keene's article in this issue on the Korean War, seen through the lens

\footnotetext{
${ }^{2}$ The growing importance of the internet as a vector of memorialism is illustrated by the multiplication of virtual monuments, like the data bank compiled by the French Ministry of Defence's Service historique de la défense (SHD) of soldiers who 'died for France' in World War I and the colonial wars of Indochina,
} 
of cinema as 'prosthetic memory,' illustrates the manufacture of collective memory through film. Channels influence not only the possibilities of dissemination, but the symbolic weight attached to the articulation of memory, in proportion to the prestige and authority attached to the mode of transmission. Equally, agency to some extent conditions the modes of articulation: official agencies, such as Departments for Veterans' Affairs, are able to marshal audiovisual resources within the mainstream media that are inaccessible to small scale non-institutional associations. However, the emergence of new popular modes of articulation like the internet has arguably democratised the field of memory by enabling peripheral agencies to reach wider audiences.

A fifth category of analysis concerns the anchoring of memory in material objects such as monuments and memorials, and topographical sites. The expression lieu de mémoire, as Pierre Nora uses it (1984-1992), covers a range of items, some material, others abstract - books, people, slogans. But the preservation of recollections rests, above all, on their anchorage in space, in what Nuala Johnson calls 'the geographies of remembrance' (2003), be they formative or framing (Graves 2009), or what we would term 'fields of memory.' The objects that surround us, 'natural' and human-made, landscapes and architecture, battle-sites and monuments, even when modelled and exhibited as diorama (as in the galleries of the Australian War Memorial in Canberra), are invested with the imprint of the human past: they become a field for recollection, a framework for rituals of remembrance. The very topography of the place, or the form of a monument, can become a metonymic representation of the event, imposing a context, channelling certain forms of remembering.

Moreover, once concretised in space, memorial places then acquire a life and significance of their own. Matthew Graves's article in this issue on the monument to the assassination of the King of Yugoslavia, Alexander I, by Croatian 'terrorists' during a state visit to Marseilles in October 1934, offers a striking example of how unpredictably the social and political meanings of a monument can evolve as the historical context changes. In the pre-war period period, the national and regional memorial agencies came into conflict over the site, form and content of the 'Pax' monument and who

\footnotetext{
Algeria, Morocco and Tunisia, which has recently been extended to include the fallen of World War II, controversially including soldiers who served the Vichy régime (Wieder 2010: 2).
} 
should build it. Political tensions in the Popular Front years reached such a pitch that the official inauguration was shelved, only to be confidentially expedited under the Vichy administration. During World War II, the monument became the focus for opposition to Vichy by the Marseilles resistance movement and a site of spontaneous popular protest, diverting its memorial meaning to hitherto unintended and unpredictable purposes. Robert Aldrich's article in this issue also offers many examples of the diverse objects and places that, recently mobilised and constructed to recall empires past, have become sites of present, previously unimagined struggle: 'Monuments and museums act not only as sites of history but as venues for political agitation and forums for academic debate.' They also provide architectural and design models, like Maya Lin Ying's Vietnam Veterans War Memorial in Washington DC (inaugurated in 1982), which, widely admired and imitated, has influenced memorial forms transculturally in fields far removed from the original commemorative context.

\section{Memory and history}

The nature of the relationship between history and memory has been a major preoccupation of the era of commemoration. Should we see them as one and the same, history as memory with pretensions to the universal, but just as biased, partial and incomplete as memory? And memory as 'present history,' just a decade or two short of critical mass? Or can we draw a distinction between the warm subjectivity of memory, the immediacy of lived experience, of family and community tradition and the cold, dispassionate objectivity of the historian, the seeker after truth? While it is impossible here to retrace in detail the defences that history has erected against the 'tidal surge' of memory, it is important to acknowledge the changing nature of the role of the historian, now drawn into an uneasy relationship with the agents of memory. The association Liberté pour l'histoire, founded by the late René Reymond in 2005 and chaired by Pierre Nora, is part of a broader movement among historians campaigning against the European-wide trend for governments (in France, Spain and Russia notably) to promote memory laws that may impinge upon the citizen's freedom of thought and expression. Liberté pour l'histoire (which has its own website) was the prime mover behind the 2008 Blois Appeal, which counts Eric Hobsbawm and public intellectuals like Timothy Garton Ash among its signatories. Its declared aim is 'to put a stop to this movement toward laws aimed at controlling history memory' ('Blois Appeal' 2008). Comparing such legislation to the Soviet practice of deciding which pasts were to be remembered, 
Eric Hobsbawm has opposed the historians' freedom of conscience to the duty of remembrance by decree: ‘The past is not a matter of political compulsion' (2008).

Pierre Nora has said that the historian is now rivalled by the witness, the victim, the journalist, the judge, and the legislator, in the context of the increasing trend towards the valorisation of 'survivor testimonies,' the trials of war criminals, and the campaigns to acknowledge past wrongs (2008: 19). But if greater weight is now attached to the value of memory and testimony, historians are often still called upon to arbitrate, or to support one side or another: their advocacy is sought because they alone can grant the imprimatur of scientific validation. Paradoxically, in the era of commemoration and the memory boom, when everyone's memory is to count, the historian still plays a crucial role - one of legitimation, the ultimate recourse in the war over memory. Ashplant et al. write: 'Arguably the historian has a place in the commemorative culture of late twentieth century as privileged as that of the war poet or monument designer in midcentury' (2004: 49). In his survey of 1980 Olivier Mongin talks of the 'consecration of the historian' and suggests that historians have filled the void created by the disappearance of the intellectuel engagé (Quoted in Jackson 1999: 242).

However, this privileged position is not, perhaps, an easy one to occupy, as the virulent so-called 'history wars' of recent years in Australia indicate. And there are occasions when history and memory collide and cannot easily be reconciled. Rechniewski's account of the conflict over the 'Battle for Australia Day' offers an illustration of the confrontation between memory and history: the wartime memories of the Australian population are mobilised to support the argument that the threat of Japanese invasion in the 1940s was real - the civilians, the residents of Darwin, the Sydneysiders who experienced an attack from a Japanese submarine, perhaps the soldiers who fought along the Kokoda track in what is now Papua New Guinea, believed the threat of imminent Japanese invasion to be genuine. Should their memories weigh as heavily in the balance of history as the clinical analyses of historians such as Peter Stanley who marshal arguments that contradict the remembered reality of this threat?

Lindi Todd's discussion of the South African Truth and Reconciliation Commission (TRC), in a paper given at the 'Histories of Forgetting and Remembering' workshop held at the University of Sydney in October 2008, reveals an inquiry uneasily poised between the historian's task of representing the past accurately, the judge's task of 
apportioning blame and guilt, and the psychologist's task of bringing 'closure,' forgiveness, the ability to 'move on.' Her paper also illustrated the problems that may result from transferring concepts from the individual to the collective level - thus a psychoanalytical concept: the 'working through trauma through talk' model of psychoanalysis was transferred to the level of the nation as a whole. But as Molly Andrews asks: 'what correspondence, if any, is there between the healing of a nation and the healing of individuals who participate in truth commission mechanisms?' (Andrews 2007: 154). There is no unified national psyche that can heal itself.

The TRC proved no exception to Marc Ossiel's conclusion that the 'fashioning of national identity through the cultivation of collective memory is almost inevitably conflictual' (1997: 255): whose memory is to be accredited, whose stifled? In the case of testimony to the TRC, who is allowed to speak? And what stories are they allowed to tell? What censorship, self or external, is exercised? Andrews suggests that only certain kinds of stories could be told, that the requirement was to identify villains and victims, rather than the shades of grey that inevitably characterise the actions of those caught up in situations of oppression of one group by another.

\section{Devoir de mémoire, devoir d'oubli?}

The devoir de mémoire - the duty of remembrance - has provoked much discussion in France over the last few decades. The debate has been in part provoked by the role the French parliament has assumed — under governments of different political hues and with diverse agendas - in legislating for history: to penalise Holocaust denial (loi Gayssot, enacted in 1990) and the denial of the existence of the Armenian genocide (enacted, 2001); to ensure that slavery would be recognised as a crime against humanity (loi Taubira, enacted 2001) and even to recognise the benefits of colonisation (enacted, 2005), a law that was eventually vetoed by the president. But do we also have a devoir d'oubli, as Marc Augé suggests, so that the individual can live in the present (2001: 119-22), and so that the nation can be reconciled with itself (Renan 1882), so that the individual, the community, the nation can forgive and move on? For Ricœur, on this point, forgiveness and forgetting, and their relationship, constitute 'the horizon of our entire investigation' (2004: 412). 
To capture the processes of forgetting is highly problematic, however, for forgetting is the silent, unacknowledged partner of remembering. The South African Truth and Reconciliation Commission is a rare example of the overt setting-in-place of processes designed to encourage forgetting and forgiveness. Rarely can the evidence be found of the texts that command forgetting: official narratives overwrite private memories without acknowledging them; monuments and memorials are built over earlier sites of memory; new school curricula focus on one area and neglect another. Robert Aldrich's article in this issue is all the more interesting, therefore, for the examples he gives of the attempts by colonial states after World War II to erase the representations, close the institutions, and mothball the artefacts that were evidence of their colonial pasts. That process continues today. Thus, to name one example from France, the vast anthropological collections of the Museum of the Arts of Africa and Oceania and the Museum of Man — gathered under the aegis of colonial France — were relocated in 2006 to the new Musée du quai Branly: 'relooké' as the French say. ${ }^{3}$

\section{Return of the national?}

The focus of academic study on remembering may have shifted in recent years to include the transnational and transcultural levels, But while the arena of public remembering remains so heavily invested by the state and national organisationsindeed the intensification of memorial activity at the national level seems to be characteristic of the contemporary world - much research remains to be done on the agents of memory at work in the national domain who control access to the resources, channels, and arenas of memory. There is a need for more research into these gatekeepers of memory, the powerful institutions at regional, national and supranational level - city councils, ministries, national and international media, veterans' organisations; as well as of the interaction and conflict between these institutions and interests - in order to better understand the agendas of remembering and forgetting. Matthew Graves's account in this issue of the political struggle between the Paris and Marseilles authorities over the right to build the Pax memorial is a case in point. For Australia we can cite the key role played by gatekeepers of memory, such as the Australian War Memorial, the Federal and State departments of Veterans' Affairs and

\footnotetext{
${ }^{3}$ As the museum's website states: 'Le musée du quai Branly ... permet de consulter l'ensemble de sa collection d'objets, soit 267417 objets. 236509 objets proviennent du laboratoire d'ethnologie du musée de l'Homme et 22740 de l'ancien Musée national des arts d'Afrique et d'Océanie' ('Le musée du quai Branly 2005).
} 
Education, the Teachers' Unions, and the RSL. The current debate over the proposed national history curriculum for high-school students promises to reveal much about the current balance of forces in the arena of memory in Australia.

As we write these lines, Australia is commemorating Anzac Day with the heightened media coverage and official sanction that have come to characterise the present era of commemoration. At the same time, a new skirmish in the so-called 'History Wars' in Australia has been provoked by two publications: Zombie Myths of Australian Military History (Stockings 2010), which includes a chapter by Peter Stanley once more seeking to debunk the 'myth' of Japanese invasion; and Marilyn Lake and Henry Reynolds' edited What's Wrong with Anzac? (2010), which inspired a virulent denunciation from Mervyn Bendle in the April 2010 issue of Quadrant. Meanwhile, in France the screening of Rachid Bouchareb's Hors-la-loi at the 2010 Cannes film festival in the wake of the anniversary of the Setif massacres of 8 May 1945 has revived FrancoAlgerian tensions over the commemoration of the victims of colonial repression and prompted an impassioned debate about the very possibility of reconciling the agents of a shared, but contested, past to the ideal of a common history ('Cinquante ans après' 2010: 8-9). These often acrimonious confrontations demonstrate just how much is at stake in conflicting narratives of national history; memory, history and individual and collective identity are inseparably bound together. As Ricœur writes: 'the narrative configuration contributes to modelling the identity of the protagonists of the action as it moulds the contours of the action itself' (2004: 85).

\section{Reference list}

Allatson, P. 2007, Latino/a Cultural and Literary Studies. Blackwell, Malden MA \& Oxford.

Anderson, B. 1983, Imagined Communities: Reflections on the Origin and Spread of Nationalism. Verso, London.

Anderson, P. 2004, 'Union sucrée,' London Review of Books, vol. 26, no. 18 (23 September), 10-16.

Andrews, M. 2007, 'South Africa: Told and Untold Stories,' in Shaping History: Narratives of Political Change. Cambridge University Press, Cambridge, 148-76.

Ashplant, T., Dawson, G. \& Roper, M. 2004, 'The Politics of War Memory and Commemoration: Contexts, Structures and Dynamics,' in The Politics of Memory: Commemorating War, (eds) T. Ashplant, G. Dawson \& M. Roper. Transaction Publishers, London, 3-85.

Augé, M. 1995, Non-Places: Introduction to an Anthropology of Supermodernity. Verso, London \& New York.

2001, Les formes de l'oubli. Edns Payot et Rivages, Paris.

Bal, M., Crewe, J. V. \& Spitzer, L. (eds) 1999, Acts of Memory: Cultural Recall in the Present. University Press of New England, Hanover, NH.

Bendle, M. 2010, 'Anzac in Ashes,' in Quadrant, vol. 54, no. 4 (April). Online, available: http://www.quadrant.org.au/magazine/issue/2010/4/anzac-in-ashes [accessed 1 May 2010].

‘The Blois Appeal.' 2008, Liberté pour l'histoire website, 12 October. Online, available: http://www.lph- 
asso.fr/index.php?option $=$ com_content $\&$ view $=$ article $\&$ id $=47 \&$ Itemid $=14 \&$ lang $=$ en $[$ accessed 26 April 2009].

Bodnar, J. 1992, Remaking America: Public Memory, Commemoration and Patriotism in the Twentieth Century. Princeton University Press, Princeton NJ.

Bouchareb, R. (dir.) 2010, Hors-la-lois, motion picture, Tessalit Productions.

Bourdieu, P. 1993, The Field of Cultural Production. Trans. R. Johnson. Columbia University Press, Columbia.

'Cinquante ans après, est-il possible d'écrire une histoire commune ?' 2010, Le Monde, 21 mai, 8-9.

Confino, A. 1997, 'Collective Memory and Cultural History: Problems of Method,' American Historical Review, vol. 102, no. 5, 1386-403.

Damousi, J. 1999, The Labour of Loss: Mourning, Memory, and Wartime Bereavement in Australia. Cambridge University Press, Cambridge.

Durkheim, É. 1893, De la division du travail social. Paris, Alcan. Trans. G. Simpson. 1933, The Division of Labor in Society. New York, Macmillan.

Erll, A. 2010, 'Travelling Memory: Remediation across Time, Space and Cultures,' Lecture given at the 'Transcultural Memory Conference' (4-6 Feb. 2010) held at the Centre for the Study of Cultural Memory, London. Video online, available: http://www.collectivememory.net/2010/03/astrid-erlltravelling-memory.html [Accessed 8 May 2010].

Foucault, M. 1984, 'Nietzsche, Genealogy, History,' in The Foucault Reader, (ed.) P. Rabinow. Pantheon Books, New York, 76-100.

Graves, M. 2009, 'Displacing Geographies of Memory: The Australian and New Zealand memorials, London.' Paper given at the AULLA conference, University of Sydney, February.

Harvey, D. 2001, 'Capitalism: The Factory of Fragmentation,' in Spaces of Capital: Towards a Critical Geography. Routledge, New York, 121-27.

Hobsbawm, E. 2008, Interview, BBC Radio 4, 18 October.

Ho Tai, H.-T. 2001, 'Remembered Realms: Pierre Nora and French National Memory,' American Historical Review, vol. 106, no. 3 (June), 906-21.

Huyssen, A. 2003, Present Pasts: Urban Palimpsests and the Politics of Memory. Stanford University Press, Stanford.

Jackson, J. 1999, 'Historians and the Nation in France,' in Writing National Histories: Western Europe since 1800, (eds) S. Berger, M. Donovan \& K. Passmore. Routledge, New York \& London, 23951.

Johnson, N. C. 2003, Ireland, the Great War and the Geography of Remembrance. Cambridge University Press, Cambridge.

Lake, M. and Reynolds, H. (eds) 2010, What's Wrong With Anzac? The Militarisation of Australian History. New South Books, Sydney.

Le Goff, J. 1992, History and Memory. Trans S. Rendall \& E. Claman. Columbia University Press, New York.

Liberté pour l'histoire website. 2005, Online, available: http://www.lph-asso.fr/index.php?option=com content\&view=category\&layout=blog\&id=1\&Itemid=5\&lang=en [accessed 26 April 2009].

Meinhof, U. \& Triandafyllidou, A. (eds). 2006, Trans-cultural Europe: Cultural Policy in a Changing Europe. Palgrave Macmillan, Basingstoke, England, \& New York.

Le musée du quai Branly website. 2005, Online, available: http://www.quaibranly.fr [Accessed 26 April 2009].

Nora, P. 1984-1992, Les lieux de mémoire. Gallimard (Bibliothèque illustrée des histoires), Paris, 3 tomes : t. 1 La République (1 vol., 1984), t. 2 La Nation (3 vol., 1986), t. 3 Les France (3 vol., 1992).

Nora, P. \& Lanzmann, C. 2008, interviewed by Jacques Julliard, 'Pourquoi légiférer sur l'histoire,' Le Nouvel Observateur, 9-15 octobre, 16-19.

Ollick, J. K. 2008, 'From Collective Memory to the Sociology of Mnemonic Practices and Products,' in Cultural Memory Studies: An International and Interdisciplinary Handbook, (eds) A. Erll \& A. Nünning. Walter de Guyter, Berlin \& New York, 151-62.

Ossiel, M. 1997, Mass Atrocity, Collective Memory and the Law. Transaction Publishers, New Brunswick, NJ.

Paletschek, S. \& Schraut, S., 2008, The Gender of Memory: Cultures of Remembrance in Nineteenth and Twentieth Century Europe. CampusVerlag, Frankfurt \& New York.

Renan, E. 1882, 'Qu'est-ce qu'une nation,' lecture delivered at the Sorbonne, 11 mars. Reproduced in Oeuvres complètes de Ernest Renan, (ed.) Henriette Psichari. Vol. 1. Paris, Calmann-Lévy, 887907.

Ricœur, P. 2004, Memory, History, Forgetting. Translated by K. Blamey \& D. Pellauer. University of 
Chicago Press, Chicago.

Robins, K. 2006, 'A Cultural Policy for European Cosmopolitanism,' in Trans-cultural Europe: Cultural Policy in a Changing Europe, (eds) U. Meinhof \& A. Triandafyllidou. Palgrave Macmillan, Basingstoke, UK, \& New York, 254-83.

Rothberg, M. 2009, Multidirectional Memory: Remembering the Holocaust in the Age of Decolonization. Stanford University Press, Stanford.

Service historique de la défense. 2010, 'Mémoire des hommes.' Ministère de la Défense, France, website. Online, available: http://www.memoiredeshommes.sga.defense.gouv.fr/index.php [Accessed 20 May 2010].

Stockings, C. (ed.) 2010, Zombie Myths of Australian Military History. University of New South Wales Press, Sydney.

Todd, L. R. 2007, 'Collective Responsibility and the Politics of Social Remembering in Post-Apartheid South Africa,' paper delivered at the 'Histories of Forgetting and Remembering' workshop hosted by the Transforming Cultures Research Centre, University of Technology Sydney, and the Faculty of Arts, University of Sydney, held at University of Sydney, 27 October.

Weber, E. 1976, Peasants into Frenchmen: The Modernization of Rural France, 1880-1914. Stanford University Press, Stanford.

Wieder, T. 2010, 'Un monument aux morts virtuel pour 39-45,' Le Monde, 20 mai, 2.

Winter, J. 2006, Remembering War: The Great War between Memory and History in the Twentieth Century. Yale University Press, New Haven \& London. 